\title{
Historical Changes in Stocking Densities on Texas Rangelands
}

\author{
Bradford P. Wilcox, ${ }^{1}$ Michael G. Sorice, ${ }^{2}$ Jay Angerer, ${ }^{3}$ and Cynthia L. Wright ${ }^{4}$
}

Authors are ${ }^{1}$ Professor and ${ }^{4}$ Undergraduate Research Assistant, Ecosystem Science and Management, Texas A ${ }^{M}$ University, College Station, TX 77843 , USA ${ }^{2}$ Assistant Professor, Department of Forest Resources \& Environmental Conservation, Virginia Tech, Blacksburg, VA 24061, USA; and ${ }^{3}$ Assistant Professor, Texas AgriLife Blackland Research and Extension Center, Temple, TX 76502, USA.

\begin{abstract}
Stocking density, both current and past, is a major determinant of the nature and condition of rangelands. Despite this fact, there have been few detailed examinations of historical trends in stocking density. We used data from the U.S. Census of Agriculture to track the density of domestic livestock from the early 1900s to the present, for six rangeland regions in the State of Texas: (1) the Edwards Plateau; (2) the Trans-Pecos; (3) the Lampasas Cut Plain; (4) the South Texas Plains; (5) the Rolling Plains; and (6) the High Plains. We find that stocking densities have declined across the state-ranging from a decline of about $40 \%$ in some regions to as much as $75 \%$ in the Trans-Pecos and Edwards Plateau regions. The period of sharpest decline, which began in the middle of the last century, reflects important, but not fully understood, socioeconomic changes. These most likely include changing land ownership, fragmentation of land holdings, and increasing emphasis on wildlife conservation. Other factors potentially contributing to the destocking of Texas rangelands include woody plant encroachment and a rise in predation. We argue that the dramatic reduction in stocking densities documented here has profound socioeconomic, ecological, and hydrological implications that need to be better understood.
\end{abstract}

\section{Resumen}

La densidad de carga en el paso y actual, es el principal determinante de la naturaleza y condición del agostadero. Después de éste hecho, ha habido pocas revisiones de la tendencia histórica y la densidad de carga en detalle. Usamos datos del Censo de Agricultura de los Estados Unidos para rastrear la densidad de animales domesticos desde inicios de los 1900s al presente, en seis regiones de pastizales en el estado de Texas. (1) La Altiplanicie Edwards, (2) La Región de Trans-Pecos, (3) La Planicie de Lampasas, (4) Las Planicies del Sur de Texas, (5) Las Planicies Onduladas y (6) Las Planicies Altas de Texas. Encontramos que las densidades de carga se han reducido a lo largo del estado - variando de una disminución del $40 \%$ en algunas regiones hasta un $75 \%$ en las regiones Trans-Pecos y La Planicie Edwards. El periodo de más reducción que inicio a mediados del siglo pasado refleja cambios socioeconómicos importantes que no están bien comprendidos. Los más probables son el cambio de propiedad, fragmentación de la tierra y el aumento en el interés de conservación de la fauna. Otros factores que potencialmente contribuyen en la descarga de los agostaderos de Texas incluyen, la invasión de plantas leñosas y un aumento en los predadores. Discutimos que esta dramática reducción de la densidad de carga aquí documentada tiene profundas implicaciones socioeconómicas, ecológicas e hidrológicas que requieren ser entendidas.

Key Words: destocking, ecological, hydrological, land fragmentation, land ownership, socioeconomic trends, wildlife conservation

\section{INTRODUCTION}

Within a given climatic and edaphic regime, rangeland condition and health are strongly affected by the region's disturbance history-including grazing, fire, and brush control (Briske et al. 2005). Because disturbance related to grazing has a particularly strong influence on range condition (Quirk 2002; Asner et al. 2004), the grazing history of a region provides an important backdrop for evaluating its current state. For example, Holechek et al. (2001) examined trends in stocking densities (the number of grazing animals per unit of land) for federal lands in the western United States from 1960 to 2005,

This research was supported by USDA-NIFA, Managed Ecosystem Grant No. 2010-85101-20485 and USDA-NIFA, CEAP Grant No 2008-51130-19562. Correspondence:

Correspondence: Dr Bradford Wilcox, Ecosystem Science and Management, Texas A\&M University, College Station, TX 77843, USA. Email: bwilcox@tamu.edu

Manuscript received 3 July 2011; manuscript accepted 30 December 2011. and demonstrated that over that period stocking densities declined by more than $50 \%$. They suggest that the general reduction in stocking densities has led to a slow but progressive improvement in overall range condition. Surprisingly, for many other rangelands in the United States, we know comparatively little about changes in stocking densities and whether patterns are similar in all regions.

Detailed inventories of animal numbers in Texas began to be compiled at the county level in the late 1800 s, and these data have been used to construct trends in stocking densities for some regions-notably the Edwards Plateau (Smeins et al. 1997; Walker et al. 2005; Wilcox et al. 2008)—but no detailed regional comparison of stocking densities on Texas rangelands has yet been done. In this article, we report on our evaluation and comparison of historical stocking densities for the major rangeland ecoregions within Texas. Stocking densities in the Edwards Plateau region have declined quite dramatically, and our research question was whether similar declines in stocking 


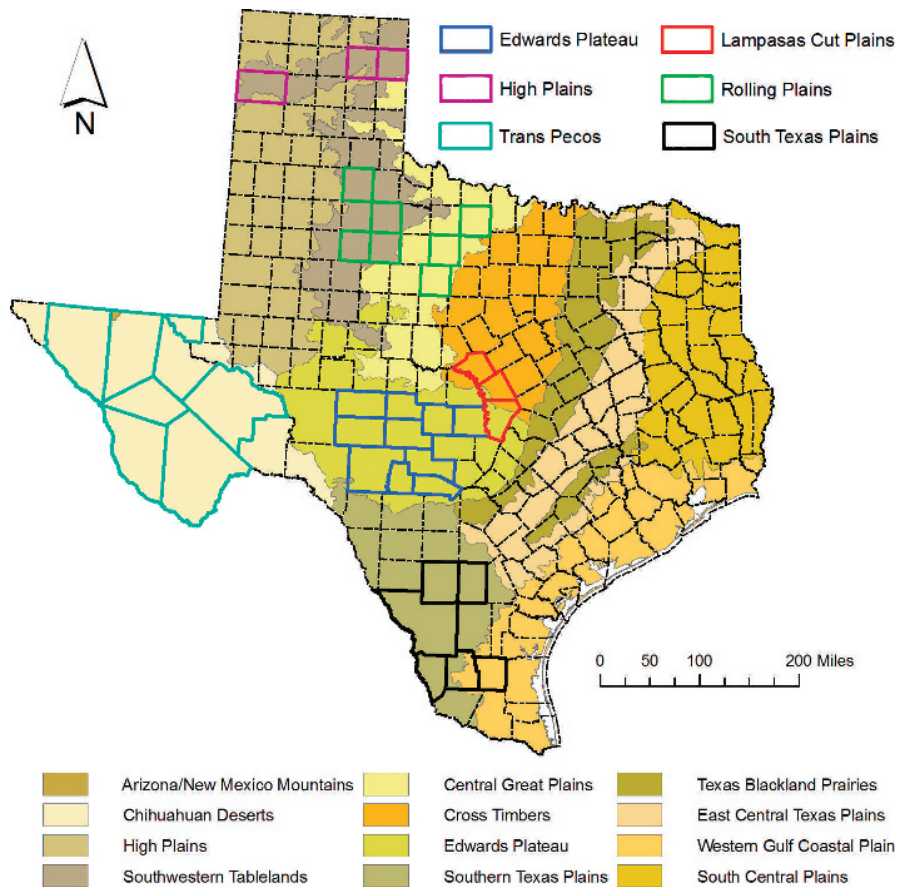

Figure 1. Counties within each region overlain on a map of the EPA ecoregions in Texas (Griffith et al. 2007).

densities have occurred in other regions of Texas. The purpose of this exploratory investigation is not only to determine the extent to which stocking densities have changed across this region, but also to formulate some hypotheses for future research: what may be driving the change, and what larger-scale effects the change might have on the ecosystem services these rangelands provide.

\section{MATERIALS AND METHODS}

We compared trends in stocking densities for six regions within Texas that are predominantly rangelands and are ecologically as well as socioeconomically distinct (Barkley and Odintz 2000; Cunfer 2005). These regions are the Edwards Plateau, the TransPecos, the Lampasas Cut Plain, the South Texas Plains, the Rolling Plains, and the High Plains. These designations correspond roughly to the EPA Ecoregions (Griffith et al. 2007) (Fig. 1). Although counties within the High Plains and Rolling Plains fall partially within the same ecoregion, we have separated them according to geographic proximity, with those counties falling east of the Caprock being grouped in the Rolling Plains and the counties to the west grouped in the High Plains. Each region includes counties that are predominantly rangeland and have been relatively unaffected by urbanization (Table 1 ).

In Texas, inventories of domestic livestock by county were documented initially at 10- and then 5-yr intervals since about 1880. These data come from three sources: preorganized Census of Agriculture data from the Great Plains Project of the University of Michigan for the period 1880-1997 (Gutmann 2005); the United States Census of Agriculture hard-copy publications for the period 1890-1997 (U.S. Census of Agriculture, 1890-2007); and the United States Census of Agriculture Web site ${ }^{1}$ for the

\footnotetext{
${ }^{1}$ http://www.agcensus.usda.gov/index.asp
}

Table 1. Relevant data for selected counties in each of the six regions examined.

\begin{tabular}{|c|c|c|c|c|}
\hline Region & County & Size $\left(\mathrm{km}^{2}\right)$ & $\begin{array}{l}\text { Average annual } \\
\text { precipitation } \\
\quad(\mathrm{mm})\end{array}$ & $\begin{array}{c}\text { Population } \\
\text { (year 2010) }\end{array}$ \\
\hline Lampasas & Burnet & 2577 & 824 & 42750 \\
\hline \multirow[t]{3}{*}{ Cut Plain } & Lampasas & 1844 & 789 & 19677 \\
\hline & Mills & 1937 & 731 & 4936 \\
\hline & & 6359 & 781 & 67363 \\
\hline Edwards & Bandera & 2050 & 909 & 20485 \\
\hline \multirow[t]{9}{*}{ Plateau } & Edwards & 5489 & 629 & 2002 \\
\hline & Kerr & 2865 & 828 & 49625 \\
\hline & Kimble & 3239 & 590 & 4607 \\
\hline & Llano & 2421 & 693 & 19301 \\
\hline & Mason & 2414 & 710 & 4012 \\
\hline & Menard & 2336 & 632 & 2242 \\
\hline & Schleicher & 3394 & 483 & 3461 \\
\hline & Sutton & 3765 & 569 & 4128 \\
\hline & & 27972 & 671 & 109863 \\
\hline \multirow[t]{8}{*}{ Trans-Pecos } & Brewster & 16037 & 437 & 9232 \\
\hline & Culberson & 9873 & 304 & 2398 \\
\hline & Hudspeth & 11837 & 303 & 3476 \\
\hline & Jeff Davis & 5864 & 403 & 2342 \\
\hline & Loving & 1743 & 231 & 82 \\
\hline & Pecos & 12336 & 357 & 15507 \\
\hline & Presidio & 9984 & 401 & 7818 \\
\hline & & 67674 & 348 & 40855 \\
\hline South Texas & Brooks & 2443 & 646 & 7223 \\
\hline \multirow[t]{6}{*}{ Plains } & Jim Hogg & 2960 & 603 & 5300 \\
\hline & La Salle & 3856 & 573 & 6886 \\
\hline & McMullen & 2882 & 606 & 707 \\
\hline & Webb & 8693 & 547 & 250304 \\
\hline & Zapata & 2581 & 496 & 14018 \\
\hline & & 23414 & 579 & 284438 \\
\hline \multirow[t]{8}{*}{ Rolling Plains } & Archer & 2356 & 756 & 9054 \\
\hline & Kent & 2337 & 583 & 808 \\
\hline & King & 2362 & 635 & 286 \\
\hline & Motley & 2562 & 582 & 1210 \\
\hline & Shackelford & 2367 & 723 & 3378 \\
\hline & Stonewall & 2379 & 590 & 1490 \\
\hline & Throckmorton & 2363 & 676 & 1641 \\
\hline & & 16726 & 649 & 17867 \\
\hline \multirow[t]{4}{*}{ High Plains } & Hemphill & 2356 & 551 & 3807 \\
\hline & Oldham & 3886 & 462 & 2052 \\
\hline & Roberts & 2393 & 592 & 929 \\
\hline & & 8635 & 535 & 6788 \\
\hline
\end{tabular}

period 2002-2007 (U.S. Census of Agriculture, 1890-2007). For our regional comparison, we compiled the numbers of grazing animals (beef cows, sheep, goats, and horses) for the selected counties within each region (Table 1). In rare instances, beef and dairy cows were not reported separately. In this case, we used the total number of cows because dairy cows make up a very small fraction $(<1 \%)$ of the total in each of the counties. For each animal type we converted total animal numbers to animal units (AUs): one AU comprises one cow, five sheep, five goats, and one horse. For each region, we determined the percent change in 

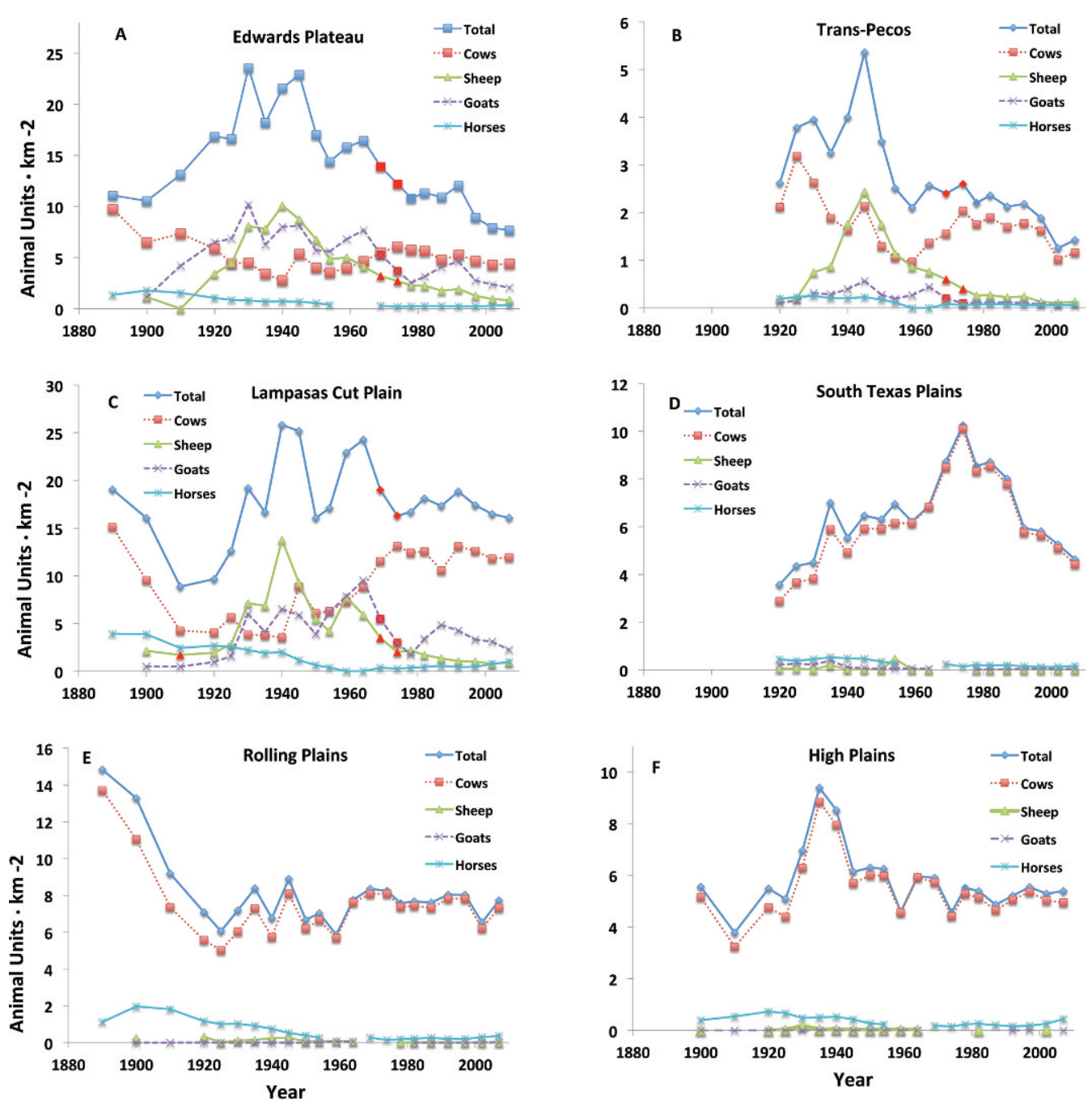

Figure 2. Historical trends in grazing intensity by domestic animals (beef cows, sheep, goats, horses) compiled from the U.S. Census of Agriculture. Data for sheep and goats were missing in 1969 and 1974 for many counties. For those years, data were filled in by assuming a linear fit between the years (1964 and 1979) for which data existed (the data points extrapolated in this way are highlighted in red).

stocking density as the difference between the peak density and the most recent year for which census data were available.

\section{RESULTS}

\section{Edwards Plateau}

The number of animal units on the Edwards Plateau peaked in 1930 and again in 1945, with a slight dip in between, perhaps due to the drought of the 1930s (Fig. 2a). Since 1945, animal units have declined by about $70 \%$, largely accounted for by a dramatic decline in the number of sheep and goats. Today some goats remain, but very few sheep. Cattle numbers initially increased slightly, partially compensating for the drop in sheep and goats, but have declined by about $30 \%$ since the 1970 s.

\section{Trans-Pecos}

Trends and patterns in the Trans-Pecos are similar to those seen in the Edwards Plateau (Fig. 2b). Grazing pressure was greatest around 1940; since that time, the number of AUs has decreased by $75 \%$. Sheep and goats, introduced into the area in the 1920s, increased rapidly in numbers until around 1940, then began to decline and today have practically disappeared. The number of cattle has declined by about $40 \%$ since the 1970 s.

\section{Lampasas Cut Plain}

Stocking densities in the Lampasas Cut Plain are similar to those of the Edwards Plateau and Trans-Pecos regions (Fig. 2c). The main difference is that cattle numbers increased more in response to the drop in sheep and goats. Even so, the total stocking level is about $40 \%$ lower than its 1945 peak.

\section{South Texas Plains}

The pattern in South Texas is different from those of the other five regions (Fig. 2d). Sheep and goats have never been an important component. Cattle numbers increased continually until about 1974, and since that time have declined by about $50 \%$.

\section{Rolling Plains}

Stocking densities in this region were greatest in the early 1900 s and, following a sharp decline of around $50 \%$, stabilized in the 1930s. They have remained relatively unchanged since that 
time, except for some slight drops during the droughts of the 1930s and 1950s (Fig. 2e). This is the only region in which animal numbers were greatest during the early 1900s.

\section{High Plains}

Stocking densities in this region peaked in 1935, then declined sharply in the 1940s (Fig. 2f). However, unlike the other regions, stocking densities have been relatively stable from the 1960 s to the present-at about $60 \%$ below their peak.

\section{DISCUSSION}

In all six regions examined, stocking densities have declined from their early or mid-20th century highs. In four of them-the Edwards Plateau, the Trans-Pecos, the Lampasas Cut Plain, and the South Texas Plains-those declines are continuing. In the other two-the Rolling Plains, and the High Plains-stocking densities have remained relatively stable for at least the past $35 \mathrm{yr}$.

Interestingly, the peak period of grazing was not consistent across regions. For three of the regions (Edwards Plateau, Lampasas Cut Plain, and Trans-Pecos), the period of greatest stocking densities was 1935-1945-accounted for by increases in sheep and goats. In the High Plains, although livestock numbers peaked around the same time, the increase was short-lived and did not consist mainly of sheep and goats. In the South Texas Plains, stocking densities increased gradually to a peak in 1974, possibly a result of the development and expansion of improved pastures with introduced species such as buffelgrass (Cenchrus ciliaris) (Hanselka 1988). Finally, in the Rolling Plains-unlike the other regions-the midcentury peak in animal numbers was attenuated and the greatest stocking densities are recorded for the early part of the 1900s. It is possible that this difference is an artifact of poor record keeping for the other regions during the early 1900s and that there are in fact more animals in all of the regions during this time than reflected in the census data. The attenuated midcentury peak in the Rolling Plains may be attributable to other factors, such as gains in income from other sources in this region: cultivated agriculture, beginning around 1910, and oil production, beginning in the 1940s (Texas State Historical Association, http://www.tshaonline.org).

The overall decline in stocking density that we have tracked in the historical records is consistent with the decline documented for western rangelands by Holecheck et al. (2001). We believe that the dramatic decline seen in the past 40-70 yr across most Texas rangelands has profound ecological as well as socioeconomic implications. Further, more detailed research is needed to identify and understand these implications, as well as the ecological and/or socioeconomic drivers that led to the overall decline in stocking densities. Below we explore some of the potential drivers as well as consequences of changing stocking densities.

\section{Potential Drivers of Declining Stocking Density}

The major drivers of change are probably not universal across all regions. Each region is different in terms of factors that affect stocking density, such as settlement patterns, land tenure, and the relative importance of wildlife.

In the Edwards Plateau, the Lampasas Cut Plain, and the Trans-Pecos, much of the decline in stocking density is related to the sharp decrease in the number of sheep and goats. This decrease is consistent with national patterns (Jones 2004). Sheep and goat numbers peaked in the 1940s, when wool was seen as a strategic commodity. Price supports for wool and mohair were put in place by the federal government in 1938, but were phased out in the 1990s (Canada 2008). Demand for wool also fell because of the development of synthetic fibers and competition from abroad. Other factors, such as increased predation and higher labor costs, may also have played a role.

A second factor that certainly comes into play is the increasing importance that landowners ascribe to wildlife, both as a source of income and for their inherent and intrinsic value (Haggerty and Travis 2006). This is particularly true in the South Texas Plains, where landowners' income from wildlife can equal or exceed that from other sources (McBryde 1998; Fulbright and Bryant 2002).

Another factor is that the nature of land ownership has changed. Landowners are less dependent on their land as a primary source of income than in the past. In addition, land values have been rising, the older population of ranchers is not being replaced by younger ones (especially with the profitability of ranching on the decline), and many urban and suburban residents are buying rural properties for the lifestyle experience (Olenick et al. 2005; Kjelland et al. 2007; Sheridan 2007). In other words, recent decades have seen a shift in land-ownership motivation: the predominant focus on agricultural production is giving way to a so-called amenity focus-valuing the rural lifestyle, the close proximity to nature and wildlife, and private recreation opportunities (Haggerty and Travis 2006; Johnson 2008; Gosnell and Abrams 2009). Additional factors possibly contributing to the decline in stocking densities are the relatively high costs for replacement cattle and the increased productivity per animal unit, which enables feedlots to maintain productivity with fewer animals (USDA-National Agricultural Statistics Service 2010).

Finally, woody plant encroachment may be contributing to the decline in stocking densities (Smeins et al. 1997). Woodlands are expanding across Texas (Archer et al. 2001; Asner et al. 2003; Wilcox et al. 2008), and such expansion translates to lower forage production in general (Archer et al. 2011).

\section{Potential Implications for Ecosystem Services}

For most rangelands, the type and abundance of vegetation cover is strongly affected by the extent to which it is grazed (Holechek et al. 2001). In general, range condition is negatively correlated with stocking density. It is very likely that the overall decline in stocking density has contributed to an increase in vegetation cover on rangelands (which certainly is the case, compared with conditions of the early and mid last century). We argue that the decline in stocking densities along with the increase in woody plants has given rise to a landscape with much more vegetation cover, biomass, and diversity than in the first half of the last century. Some of these changes are reasonably well documented and others are not. All of them need to be better quantified, but clearly they significantly affect both ecosystem functioning and the ecological services provided by rangelands.

On a regional scale, the increased vegetation cover most certainly translates into enhanced ecosystem services, including both hydrological services (protection from erosion, reduction in 
flooding, greater groundwater recharge, and better water quality) and ecological services (more biodiversity, carbon sequestration, wildlife habitat, viewsheds, etc.). Although additional research is needed to quantify better how changes in animal numbers have altered rangeland ecosystems, some of these linkages are reasonably well established. For example, recent studies have documented a number of regional-scale hydrological changes that have occurred, including a reduction in flooding (Wilcox et al. 2008), increases in spring flow (Wilcox and Huang 2010), and decreases in erosion (Dunbar et al. 2010). Furthermore, a significant body of work has established the positive relationship between vegetation biomass and carbon sequestration, as well as the general benefit to wildlife and species diversity with increasing vegetation (Archer et al. 2011). Greater vegetation biomass also means higher fuel loads, which are likely contributing to the unprecedented increase in the size and frequency of large-scale wildfires on Texas rangelands, such as those witnessed in the spring of 2011.

\section{MANAGEMENT IMPLICATIONS}

Stocking densities have declined across rangelands in Texas, and are continuing to decline in a great many of them. The numbers of sheep and goats have seen the most dramatic decline. We suggest that this overall decline has been driven by a variety of socioeconomic factors, such as changing land ownership and the increasing importance of wildlife conservation, but these relationships need to be evaluated in more detail. The ensuing combination of reduced grazing pressure and woody plant encroachment most certainly have given rise to greater vegetation cover and biomass compared with conditions during the first half of the last century. Although the effects of these changes are not fully understood, they clearly are important-including increased risk of large fires, increases in carbon sequestration, improved hydrological conditions, and in many cases improved habitat for wildlife. We argue, therefore, that these changes have profound implications for managers and policy makers, including the need for regional-scale fire management programs and reassessment of the ecosystem services provided by rangelands.

\section{ACKNOWLEDGMENTS}

We are grateful to John Walker, Charles (Butch) Taylor, Richard Conner, and Mort Kothman, all of whom provided helpful input.

\section{LITERATURE CITED}

Archer, S., T. W. Boutton, and K. A. HibBard. 2001. Trees in grasslands: biogeochemical consequences of woody plant expansion. In: E. D. Schulze, S. P. Harrison, M. Heimann, E. A. Holland, J. Lloyd, I. C. Prentice, D. Schimel [eds.]. Global biogeochemical cycles in the climate system. Durham, NC, USA: Academic Press. p. $115-138$.

Archer, S., K. W. Davies, T. E. Fulbright, K. C. McDaniel, B. P. Wilcox, and K. I. PREDICK. 2011. Brush management as a rangeland conservation tool: a critical evaluation. In: D. D. Briske [ED.]. Conservation effects assessment project. Washington, DC: USDA-NRCS.

Asner, G. P., S. Archer, R. F. Hughes, R. J. Ansley, and C. A. Wessman. 2003. Net changes in regional woody vegetation cover and carbon storage in Texas Drylands, 1937-1999. Global Change Biology 9:316-335.
Asner, G. P., A. J. Elmore, L. P. Olander, R. E. Martin, and A. T. Harris. 2004. Grazing systems, ecosystem responses, and global change. Annual Review of Environment and Resources 29:261-299.

Barkley, R. R. and M. F. Odintz [eds.]. 2000. The portable handbook of Texas. Austin, TX, USA: Texas State Historical Association. 1072 p.

Briske, D. D., S. D. Fuhlendorf, and F. E. Smeins. 2005. State-and-transition models, thresholds, and rangeland health: a synthesis of ecological concepts and perspectives. Rangeland Ecology \& Management 58:1-10.

CanadA, C. 2008. Wool and mohair price support. CRS Report to Congress: Washington, DC.

Cunfer, G. A. 2005. On the Great Plains: agriculture and environment. College Station, TX, USA: Texas A\&M University Press.

Dunbar, J. A., P. M. Allen, and S. J. Bennett. 2010. Effect of multiyear drought on upland sediment yield and subsequent impacts on flood control reservoir storage. Water Resources Research 46:W05526. doi:10.1029/2008WR007519

Fulbright, T. E., And F. C. Bryant. 2002. The last great habitat. Kingsville, TX, USA: Caesar Kleberg Wildlife Research Institute.

Gosnell, H., And J. Abrams. 2011. Amenity migration: diverse conceptualizations of drivers, socioeconomic dimensions, and emerging challenges. GeoJournal 76:303-322.

Griffith, G., S. Bryce, J. Omernik, and A. Rogers. 2007. Ecoregions of Texas. Austin, TX, USA: Texas Commission on Environmental Quality. 125 p.

Gutmann, M. P. 2005. Great Plains Population and Enviroment Data: Social and Demographic Data, 1870-2000. Ann Arbor, MI, USA: Inter-university Consortium for Political and Social Research, University of Michigan.

HaggerTy, J. H., AND W. R. Travis. 2006. Out of administrative control: absentee owners, resident elk and the shifting nature of wildlife management in southwestern Montana. Geoforum 37:816-830.

HanselkA, C. W. 1988. Buffelgrass-South Texas wonder grass. Rangelands 10:279-281.

Holechek, J. L., R. D. Pieper, and C. H. Herbel. 2001. Range management: Principles and practices. Upper Saddle River, NJ, USA: Prentice Hall.

Johnson, B. E. 2008. Nature, affordability, and privacy as motivations for exurban living. Urban Geography 29:705-723.

Jones, K. G. 2004. Trends in the U.S. sheep industry. Washington, DC, USA: USDA Economic Research Service.

Kuelland, M. E., U. P. Kreuter, G. A. Clendenin, R. N. Wilkins, X. Ben Wu, E. G. Afanador, and W. E. Grant. 2007. Factors related to spatial patterns of rural land fragmentation in Texas. Environmental Management 40:231-244.

McBryde, G. 1998. Effects of range management on the lower Rio Grande watershed. Journal of Arid Environments 40:217-233.

Olenick, K. L., U. P. Kreuter, And J. R. Conner. 2005. Texas landowner perceptions regarding ecosystem services and cost-sharing land management programs. Ecological Economics 53:247-260.

QuiRK, M. 2002. Managing grazing. In: A. C. Grice and K. C. Hodgkinson [EDS.]. Global rangelands: progress and prospects. New York, NY, USA: CABI Publishing. p. 131-146.

Sheridan, T. E. 2007. Embattled ranchers, endangered species, and urban sprawl: the political ecology of the new American West. Annual Review of Anthropology 36:121-138.

Smeins, F. E., S. D. Fuhlendorf, and C. A. Taylor. 1997. Environmental and land use changes: a long-term perspective. In: J. Ansley [ED.]. Juniper symposium. San Angelo, TX, USA: Texas A\&M University. p. 3-21.

uSDA-National Agricultural Statistics Service. 2010. Overview of the United States cattle industry. Available at: http://usda.mannlib.cornell.edu/usda/current/ USCatSup/USCatSup-12-17-2010.pdf. 15 p.

Walker, J. W., J. L. Johnson, and C. A. Taylor, JR. 2005. Challenges and opportunities for sustainable rangeland pastoral systems. In: J. A. Milne [ED.]. Pastoral systems in marginal environments. Wageningen, The Netherlands: Wageningen Academic Publishers.

Wilcox, B. P., And Y. Huang. 2010. Woody plant encroachment paradox: rivers rebound as degraded grasslands convert to woodlands. Geophysical Research Letters 37:L07402. doi:10.1029/2009GL041929

Wilcox, B. P., Y. Huang, and J. W. Walker. 2008. Long-term trends in streamflow from semiarid rangelands: uncovering drivers of change. Global Change Biology 14:1676-1689. 